Maurer School of Law: Indiana University

Digital Repository @ Maurer Law

2010

\title{
The IFC's New Africa, Latin America, and Caribbean Fund: Its Worrisome Start, and How to Fix It
}

Christiana Ochoa

Indiana University Maurer School of Law, cochoa@indiana.edu

Patrick J. Keenan

University of Illinois College of Law

Follow this and additional works at: https://www.repository.law.indiana.edu/facpub

Part of the Business Organizations Law Commons, International Business Commons, and the International Law Commons

\section{Recommended Citation}

Ochoa, Christiana and Keenan, Patrick J., "The IFC's New Africa, Latin America, and Caribbean Fund: Its Worrisome Start, and How to Fix It" (2010). Articles by Maurer Faculty. 1312.

https://www.repository.law.indiana.edu/facpub/1312

This Article is brought to you for free and open access by the Faculty Scholarship at Digital Repository @ Maurer Law. It has been accepted for inclusion in Articles by Maurer Faculty by an authorized administrator of Digital Repository @ Maurer Law. For more information, please contact rvaughan@indiana.edu. 


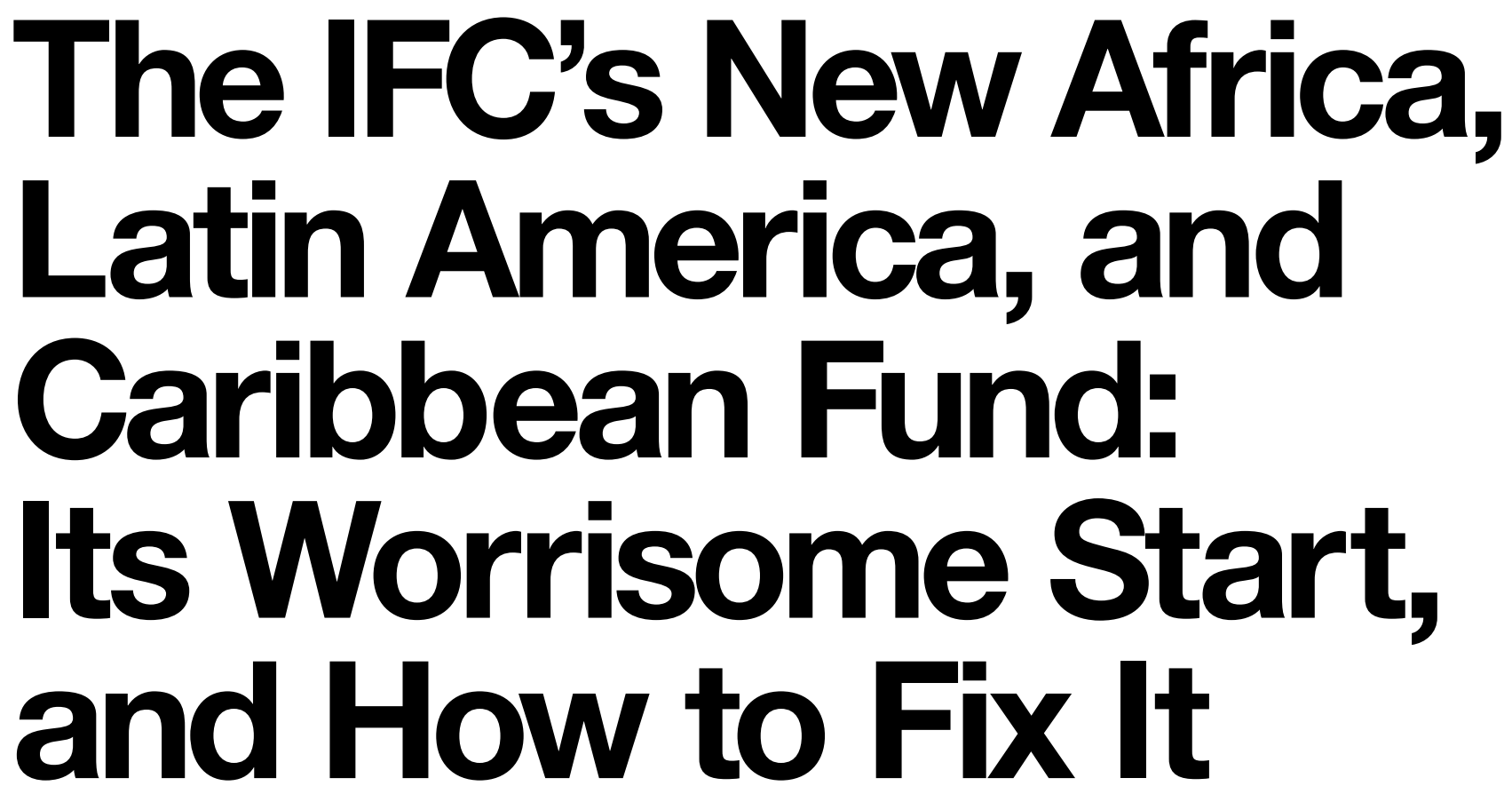

Patrick J. Keenan - Professor of Law, University of Illinois

Christiana Ochoa - Professor of Law, Indiana University - Bloomington

\section{Abstract}

In April 2010 the International Finance Corporation announced the creation of the African, Latin American, and Caribbean fund, a new co-investment vehicle funded largely with commitments from sovereign wealth and pension funds. The fund's objective was to draw on the IFC and the World Bank's strengths in emerging markets to identify and support enterprises that might not otherwise have come to the attention of large investors and thereby help strengthen the private sector and alleviate poverty in some of the world's poorest countries. Unfortunately the fund has, so far, proven a disappointment. It has invested only in large corporations that were already well known to investors. The fund should return to the principles that seemed to motivate its creation: direct engagement with private enterprises, rather than politically-connected financial intermediaries; leveraging the World Bank's superior knowledge and understanding of emerging markets, rather than investing in corporations listed in London or Frankfurt; and providing capital to small- and medium-sized enterprises that would otherwise not have the support needed to grow and compete nationally or globally. 
On April 12, 2010, the International Finance Corporation (IFC) announced the creation of a new fund that will make equity investments in companies in the developing world [Zoellick (2008)]. The new fund, called the Africa, Latin America, and Caribbean fund (or ALAC) is a vehicle through which sovereign wealth funds and pension funds can co-invest with the IFC in equity investments in emerging markets [IFC (2010a)]. The ALAC fund represents the fulfillment of World Bank president Robert Zoellick's call for sovereign wealth funds to direct one percent of their investments to private enterprises in Africa [IFC (2010a)]. Zoellick argued that investments by sovereign funds, if done in partnership with the IFC, could help to transform the economies of many poor countries. The ALAC fund was not a complete fulfillment of Zoellick's vision: he called for investments of approximately U.S. $\$ 1$ billion in Africa alone; at its inception the ALAC fund had commitments of approximately U.S. $\$ 600$ million, to be used in Africa, Latin America, and the Caribbean. The ALAC fund is managed by the IFC and is a co-investment fund, meaning that it only invests in projects in which the IFC is also investing [IFC (2010a)]. Consequently, despite being smaller and less focused that Zoellick might have hoped, the ALAC fund is a significant new player in the emerging market equity game, and for this reason alone warrants some attention as it begins its work. It has the potential to substantially influence the nascent but important emerging market private equity industry for good or ill, depending on the kinds of investments it makes and the conditions associated with those investments. In this article, we attempt to accomplish three objectives. The first is to analyze the potential for the ALAC fund to accomplish the IFC's stated goals, particularly in light of the markets in which the fund will make its investments. Second, we review the ALAC fund's initial investments and show that, despite the best intentions, the fund appears not to have learned from past mistakes, making it likely to repeat them. Finally, we conclude by proposing several reforms that, taken together, would increase the likelihood that the ALAC fund's investments would improve the welfare of the people in countries in which it invests.

\section{Do infusions of wealth improve welfare?}

It is an article of faith among most - but certainly not all - economic development professionals that poor countries need more wealth transfers to achieve economic development. Different strands of this dominant approach to development focus on transfers in the form of official development assistance, foreign direct investment, or the sale of exploitable natural resources. What unites them is the faith that transferring wealth will improve welfare. The problem with this theory is that the evidence simply does not support it. To be sure, wealth transfers can improve welfare. But it is not inevitable that wealth transfers will improve welfare. What matters more than the kind of transfer are the conditions associated with those transfers.

For wealth transfers to be effective, they must generate the incentives necessary to ensure that the recipients of that wealth use it to benefit ordinary citizens rather than to provide support to the ruling regime or to a small handful of elites. Put slightly differently, wealth transfers are unlikely to be effective tools of development unless someone - investors, citizens, regulators - has the capacity to hold accountable managers of that wealth if they steal, abuse, or misuse it. This accountability could come from an informed citizenry that votes out politicians who misuse the country's resources or from investors who punish poor stewards of wealth. These mechanisms are not novel, but they are also not particularly relevant in many of the places where development has lagged. For example, it is simply not realistic to assume that the citizens of Nigeria will have the information and governance tools necessary to punish their leaders, who have squandered billions of dollars of that country's oil riches. Or for investors in corporations whose supply chains begin - often without the end-user's full knowledge - in the squalid mines of the Democratic Republic of Congo.

To address these real-world problems, it is important to incorporate safeguards that might not be necessary in other investment contexts. Three principles are most important for such a fund. First, the fund should avoid, to the extent possible, channeling funds through governments, either directly or indirectly. The reason for this is to reduce opportunities for politicians to abuse wealth transfers for political purposes or private enrichment. Second, the fund should facilitate direct engagement between managers and the targets of investments. The goal of this is to help transfer knowledge as wealth is transferred and to provide more direct oversight in the target enterprises. In practical terms, this would mean avoiding investments in intermediaries. Third, the fund should aim low: invest in small- and mid-sized enterprises. Such a strategy is inevitably less efficient than targeting large, well-established enterprises, but the IFC's reason for existing, and its role as co-investor, is to handle such inefficiencies.

One strand of the "transfer wealth, improve welfare" approach centers on official development assistance. For some of the world's most influential economists, this means that the governments of relatively wealthy countries should transfer more money to the governments of relatively impecunious countries. Economist Jeffrey Sachs of Columbia University is perhaps the most prominent purveyor of this approach through his advocacy of the Millennium Development Goals. The MDGs were developed by the United Nations as a set of benchmarks, the achievement of which would indicate a significant reduction in poverty and improvement in welfare. For Sachs and others, the principal impediment to the achievement of the MDGs is "the donor shortfall in honoring specific financial commitments to Africa" and other countries [Sachs (2010)].The problem, in other words, is that rich-country governments are not transferring enough money to poorcountry governments: were these transfers to occur, then poor countries would be able to pull themselves out of poverty. Even among economists who disagree almost as a matter of course, there is agreement that development assistance has not produced the hoped-for results. For example, William Easterly, a prominent skeptic of development assistance, at least 


\section{The Capco Institute Journal of Financial Transformation}

as it has typically been delivered, has argued that there have been virtually no positive effects from aid [Easterly et al. (2004)]. On this point Easterly agrees with David Dollar, who is much less skeptical of foreign assistance in general, but who also notes that aid has had very little positive effect in recipient countries [Burnside and Dollar (2000)]. In addition, development assistance has not just been less effective than intended. Just as with resource revenue, aid also appears to contribute to a reduction in welfare and an erosion of governance [Knack (2001)]. For example, foreign aid appears to contribute to an increase in official corruption as politicians compete for the control of the wealth [Alesina and Weder (2002)]. Aid dependence can also undermine the quality of a country's institutions of governance and erode democracy [Djankov et al. (2008)]. To be sure, there are examples of development projects that have worked. Nonetheless, over the long term, foreign aid has not contributed to growth [Clemens et al. (2004)].

A second strand of the "transfer wealth, improve welfare" school centers on the potential for resource wealth to transform the economies of poor countries. Countries whose economies are heavily dependent on revenue from the sale of natural resources have not fared as well as countries without such resource wealth. Research on the resource curse, as it is often labeled, has shown that many countries that are heavily dependent on revenue from a single resource have weaker economies, other things equal, than similarly-situated countries that do not possess the valuable resource [Keenan and Ochoa (2009)]. The first, and still leading, article on this issue came from Jeffrey D. Sachs and Andrew M. Warner, who analyzed the role of natural resource wealth in development [Sachs and Warner (1995)]. Sachs and Warner used a database of 97 resource-rich countries and compared each country's growth rate to its level of resource dependence. Even after controlling for a number of other variables, Sachs and Warner found "a statistically significant, inverse, and robust association between natural resource intensity and growth." [Sachs and Warner (1995)]. Although it is typically referred to as the "resource curse" [Auty (1993)], the phenomenon was initially called the "Dutch disease" [Economist (1977)], a term used to describe the effects on an economy resulting from the sale of natural resources [Collier (2007)]. Recent research has shown that resourcedependent economies face a number of other ills: a possible increase in official corruption [Tornell and Lane (1999)], a greater likelihood of conflict [Aslaksen and Torvik (2006)], a misallocation of resources [Robinson and Torvik (2005)], longer tenure for leaders of the ruling regime [Smith (2004)], and reductions in various measures of social welfare.

A final strand of the "transfer wealth, improve welfare" school holds that it is private investment, not official development assistance, that is most likely to help the poorest countries grow. Investment by foreign corporations in poor countries is, of course, not new. What is new is the argument that private-sector investment is a surer path to economic development than official development assistance or the sale of natural resources. Researchers have long known that foreign investment can act as a net drain on the wealth of developing countries [Evans (1971)]. Contrary to the typical assumptions, there is ample empirical evidence demonstrating that FDI often slows growth [Kosack and Tobin (2006)]. This is particularly true in poor countries. Interestingly, resource-rich countries may perform even worse with $\mathrm{FDI}$ as private investment can deprive them of monetary gains while, at the same time, diminishing their long-term potential (in the form of retained natural resources) for economic development [Ochoa (2008)].

To evaluate the new ALAC fund it is not sufficient to show that infusions of wealth can reduce welfare. It is also important to identify some of the reasons why this is true. One explanation is that when individuals perceive that there is one and only one way to become wealthy, they follow it to the exclusion of other options. Put another way, rent-seeking amounts to "[c]utting yourself a bigger slice of the cake rather than making the cake bigger." [Bishop (2004)]. When politicians in power can depend on revenue from the sale of a natural resource to fund their regime and the institutions of government, they are relieved of the need to make the politically difficult choices that might support broad-based economic development. For example, when a regime can fund itself by selling natural resources, "the state has less need for taxation of the population, and without the pressure for taxation the state has less need to develop mechanisms of deep control of the citizenry." [Isham et al. (2005)]. In addition, a regime can use unconditioned wealth to support politically useful but economically unsound investments [Kolstad et al. (2009)]. In Nigeria, for example, to placate its supporters, the government has invested heavily in manufacturing. Unfortunately, because the true objective of the government's investments was political, not economic, those investments have contributed little to economic growth. According to one recent empirical study of Nigeria, "two-thirds of the investment in manufacturing by the government is consistently wasted." [Sala-i-Martin and Subramanian (2003)]. When politicians manage assets with only political objectives in mind, they can make bad investment decisions. In perhaps the most complete account of this phenomenon, Michael Ross has shown that politicians in Indonesia, Malaysia, and the Philippines were motivated by the rents available from timber sales and undermined national and local institutions in order to exploit the timber [Ross (2001)]. Similarly, a recent report has demonstrated this phenomenon among Cambodia's ruling elite [Global Witness (2009)].

\section{The ALAC fund's wobbly first steps}

The ALAC fund was born of the World Bank's best intentions and is the kind of investment vehicle that could, under the right circumstances, help to improve the lives of some of the poorest people in the world. When the fund was created, World Bank's Robert Zoellick described it as an attempt to harness the "significant savings pool" represented by "pension and sovereign funds" seeking "commercial returns and portfolio diversification." [IFC (2010a)]. The fund is managed by the IFC's Asset Management Company, LLC, a wholly-owned subsidiary of the IFC. Because the 
IFC has been slow to release detailed information about the ALAC fund, it is difficult to pinpoint the fund's strategy. When the fund was created, the CEO of the IFC described it as part of the IFC's overall strategy of providing "co-investment opportunities to sovereign and pension fund investors." [IFC (2010a)]. Investors in the fund indicated that they had two objectives beyond earning a return and diversifying their portfolios: greater access to "frontier markets" and "sustainable investment opportunities." [IFC (2010a)].

To date the ALAC fund has announced four investments, three in Africa and one in the Caribbean. It is, of course, difficult to draw any firm conclusions about the fund's strategy based on a small number of investments made over the course of one year. But the initial decisions are not encouraging. Unfortunately the ALAC's funds initial investments are not consistent with the principles that would make it a viable tool for accomplishing its dual goals: facilitating development and poverty reduction, and providing a return to investors. Three of the fund's first four investments have been in financial institutions - intermediaries that are one step removed from the entrepreneurs whose work can actually fuel economic growth. The fourth investment is in a German cement company whose work is largely in infrastructure.

Three of the ALAC fund's first four investments have been in financial services companies. So far the fund has invested in Ecobank Transnational, a bank with operations throughout Africa, Guaranty Trust Bank, a Nigerian bank, and Guardian Holdings, a Caribbean insurance company. The fourth investment is in HeidelbergCement, a German group with substantial operations in West Africa. None of these investments is the kind that is likely to promote ground-level development, avoid the risk of corruption or politicized decision making, and transfer knowledge and expertise to entrepreneurs.

One problem is the size of the fund's investment targets. At first blush there is little reason to be skeptical of investments in these four enterprises. All are well-established players in their respective industries and known to the IFC and other international financial institutions. But it is these very qualities that give us pause. The ALAC fund's investment strategy has been only hazily disclosed, but there are two likely strategies. Either the fund is seeking conventional investments that are attractive to the fund for the same reasons they would be attractive to any other investor, or it is seeking unconventional opportunities that it has reason to believe can deliver a return with sufficient knowledge transfer, oversight, or support. Thus, if the ALAC fund chose its initial investments because they are strong players, well positioned to provide a solid market return on investment, then the fund simply put its money where many other investors would have been willing to put their money. then the IFC should have left these investments to the market. This is particularly true of Guaranty Trust Bank, the Nigerian bank that was the recipient of the fund's third investment. Guaranty Trust Bank is listed on the London Stock Exchange (and the Nigerian Stock Exchange), which should provide it with access to necessary capital. This is not to suggest that the fund should never invest in a listed enterprise, but such an investment clearly does not fulfill the IFC's stated goal of using its superior knowledge of emerging markets to identify investment opportunities that other investors would fail to recognize.

The fund's investment in HeidelbergCement is perhaps even more puzzling. HeidelbergCement is the fourth-largest cement company in the world [HeidelbergCement (2010)]. It does business worldwide and is listed on the German stock exchanges. It hardly seems the kind of company that the IFC is uniquely positioned to recognize as a valuable investment target, or the kind of company that needs funds from an international financial institution to signal to the markets that it is a viable enterprise poised for growth. If the ALAC fund was actually seeking to support enterprises with the potential to deliver a return and deliver on the IFC's development mission as well, then the fund chose the wrong targets.

A second problem is that three of the four recipients of investment are financial intermediaries. If the ALAC fund is to be different and more effective than any other private equity investor, then it should focus on small and medium-sized enterprises. Most international financial institutions find it difficult to oversee the quantity of SME investments that would be necessary to have a meaningful impact on development and provide a market return to investors. This concern is real, but the IFC is - or ought to be - different. Its mission is to help alleviate poverty by promoting private sector development. There is surely something to the conventional wisdom that support for regional banks can have a multiplier effect by helping to solidify private equity markets in new areas and signaling international confidence in markets thought to be unstable. But the IFC's goal in creating the ALAC fund was to provide these benefits by taking equity stakes in enterprises that were not otherwise known to most investors; something it has so far failed to do.

A third problem with the fund's initial investments is that it has chosen companies that are sufficiently large to be politically important, and that operate in markets that are sufficiently risky to make them need government favor to thrive. Indeed, two of the reasons the IFC gave for choosing to invest in Guaranty Trust Bank in Nigeria are telling: one was to signal its "confidence in Nigerian banking reforms," and another was to show support for the "Central Bank's initiatives to strengthen the overall banking sector." [IFC (2010b)]. Ecobank, another early recipient of the fund's investment, was accused of complicity in the bloody wars in West Africa as the bank that received payments for illicit timber sales that fueled the war for years [Carvajal (2010), Global Witness (2009)]. Ecobank thrived 


\section{The Capco Institute Journal of Financial Transformation}

because it was connected to those with power, and it has a recent and well-publicized history as banker to warlords. Nonetheless the IFC chose it as one of its initial investment targets.

\section{Conclusion: creating a fund that could make a difference}

Putting the ALAC fund on the right path would take courage, but has the potential to do enormous good. The fund should return to the principles that seemed to animate Robert Zoellick's initial vision for such a fund: direct engagement with private enterprises, leveraging the World Bank's superior knowledge and understanding of emerging markets, and providing capital to small- and medium-sized enterprises that would otherwise not have the support needed to grow and compete nationally or globally.

The IFC exists to work with private enterprises, and does so all the time. But its approach to engagement with private enterprises appears to be indifferent to what those enterprises do. One typical argument for development assistance and investment by international financial institutions is that these investments can improve the capacity of host-country institutions and improve the rule of law. Our approach is different. We argue for direct engagement with private enterprises as a way to enable those enterprises to strengthen local institutions. Recent history is rife with examples of development assistance and foreign investment in large, politically-connected firms that resulted in an erosion of local institutions, not an improvement. Our approach would give local enterprises the wherewithal to compete in the marketplace, and thereby enhance the vitality of local communities and create a base for reform of local institutions. The ALAC fund's initial investments are all in large, well-established, politically-connected enterprises with little or no incentive to push for meaningful institutional reform.

When it created the ALAC fund, the World Bank and the IFC indicated that the fund would be a vehicle through which investors could earn a return by relying on the World Bank's superior knowledge of emerging markets and its ability to work directly in some of the most challenging environments in the world. Such a fund would indeed have the potential to generate a market return and fulfill the World Bank's poverty-alleviation mission. Unfortunately, that is not what the ALAC fund has done, at least so far. Based on its initial investments, there is nothing to indicate that the World Bank or the IFC have leveraged any special knowledge, experience, or understanding to identify investment opportunities that would not have been apparent to other investors.

The ALAC fund provided the IFC with an opportunity to strengthen its move toward working with small- and medium-sized enterprises. It is these enterprises that have the best potential to transform emerging economies and actually improve the welfare of local people. Once again, the ALAC fund has not pursued this approach. Instead it has targeted large, well-established enterprises that are not likely to transform local economies or improve the lives of local people.

Based on its track record so far the ALAC fund must be considered a missed opportunity. But if the fund refocused its strategy to work directly with smaller, less politically dependent enterprises, and it began to search for and find investment targets not known to other investors, then it might fulfill its potential.

\section{References}

- Alesina, A., and B. Weder, 2002, "Do corrupt governments receive less foreign aid?" American Economic Review, 92, 1126-1127

- Aslaksen, S., and R. Torvik, 2006, "A theory of civil conflict and democracy in rentier states," Scandinavian Journal of Economics, 108, 571-585

Auty, R., 1993, Sustaining development in mineral economies: the resource curse thesis, Routledge

Bishop, M., 2004, Essential economics, Economist Books

Burnside, C., and D. Dollar, 2000 "Aid, policies and growth," American Economic Review, 90:4, 847-868

Carvajal, D., 2010, "Hunting for Liberia's missing millions," New York Times, May 20

- Clemens, M. A., S. Radelet, R. Bhavnani, 2004 "Counting chickens when they hatch: the short term effect of aid on growth," Working Paper 40, Center for Global Development

- Collier, P., 2007, The bottom billion: why the poorest countries are failing and what can be done about it, Oxford University Press

- Djankov, S., J. Montalvo, and M. Reynal-Querol, 2008, "The curse of aid," Journal of Economic Growth, 13:3, 169-194

Easterly, W., R. Levine, and D. Roodman, 2004 "Aid, policies, and growth: comment," American Economic Review, 94:3, 774-780

Economist, 1977, "The Dutch disease," November 26, 82-83

Evans, P. B., 1971, "National autonomy and economic development: critical perspectives on multinational corporations in poor countries," 25, 675-692

Global Witness 2009, Country for sale

IFC, 2010a, "Azeris, Dutch, Koreans, Saudis invest in the IFC African, Latin American, and Caribbean fund," Press Release

- IFC, 2010b, "IFC and IFC ALAC Fund invest in Guaranty Trust Bank to demonstrate confidence in Nigerian banking reforms," Press Release

Isham, J., M. Woolcock, L. Pritchett, G. Busby, 2005 "The varieties of resource experience: natural resource export structures and the political economy of the resource curse," World Bank Economic Review, 19:2, 141-174

- Keenan, P., and C. Ochoa 2009, "The human rights potential of sovereign wealth funds," Georgetown Journal of International Law, 40:4, 1151-1180

Knack, S., 2001, "Aid dependence and the quality of governance: cross-country empirical tests," Southern Economic Journal, 68:2, 310-329

Kolstad, I., A. Wiig, and A. Williams, 2009, "Mission improbable: does petroleum-related aid address the resource curse?" Energy Policy, 37:3, 954-965

Kosack, S., and J. Tobin, 2006, "Funding self-sustaining development: the role of aid, FDI and government in economic success," International Organization, 60, 205-243

Ochoa, C., 2008, "From odious debt to odious finance: avoiding the externalities of a functional odious debt doctrine," Harvard Journal of International Law, 49, 109-159

- Robinson, J., and R. Torvik, R., 2005, "White elephants," Journal of Public Economics, 89, 197-210

Ross, M., 1999, "The political economy of the resource curse," World Politics, 51, 297-322

- Ross, M., 2001, Timber booms and institutional breakdowns in Southeast Asia, Cambridge University Press

Sachs, J., 2010, "Millennium goals, five years to go," International Herald Tribune, September 17

- Sachs, J., and A. Warner, 1995, "Natural resource abundance and economic growth," Working Paper 5398, National Bureau of Economic Research

Sala-i-Martin, X., and A. Subramanian, 2003, "Addressing the natural resource curse: an illustration from Nigeria," Working Paper 9804, National Bureau of Economic Research

- Smith, B., 2004, "Oil wealth and regime survival in the developing world, 1960-1999, American Journal of Political Science, 48:2, 232-246

. Tornell, A., and P. Lane, 1999, "The voracity effect," American Economic Review, 89:1, 22-46 